\title{
Halal Japanese Culinary as Attraction for Muslim Travellers to Visit Japan
}

\author{
Dina Hariani \\ Post Graduate Student \\ Sekolah Tinggi Pariwisata Trisakti \\ Jakarta, Indonesia \\ bhi.dinahariani@gmail.com
}

\begin{abstract}
Nowadays, many Muslim tourist who do travelling. One of the countries visited for travelling is Japan. Japan became the country's favorite foreign tourists visited by because Japan has a lot of tourist destinations, cultural, and culinary that attract many tourist . It is a concern for Muslim tourists who will visit Japan is having trouble finding Halal food. Eating Halal food is a must for a Muslim. Halal is an Arabic word which means lawful in Sharia, and refers to what a Muslim can eat satisfactorily. In general it is required to carry out the contraindications of pork, alcohol, and its derivative, and to be processed according to Sharia also about the other foods, and it is also forbidden that Halal food and the other food contact. Seeing the increasing number of Muslim tourists to Japan, the Japanese government start to provide a hospitality service to embrace more Muslim tourist through the concept of Muslim Friendly or Halal Tourism that the main point is to provide Halal food. With the availability of Halal food in Japan, they hope the Muslim tourist who come to Japan can enjoy the typical culinary of Japan without having to worry about the Halalness. Some of restaurants in Japan already had a halal logo that verified by Halal association in Japan, but there are also some restaurant in Japan that dont have the halal logo but they serve food that a Muslim can eat. This study uses a qualitative method. In order to obtain primary data using observation, survey, documentation and literature study. This study focuses on the development of Halal culinary in Japan, identified the major cities in Japan that has been providing Halal culinary, what kind of Halal Japanese culinary and find out if the availability of Halal culinary in Japan make Muslim tourist interested in visiting Japan.
\end{abstract}

Keywords-Halal, Culinary, Japan

\section{INTRODUCTION}

Japan is one of the nation's favorite foreign tourists. Japan has a lot of tourist destinations, cultural and culinary. Culinary is one of the things that are important when doing tours. When people do travel they definitely want to taste the typical food of the area. Japan's population is mostly practice Buddhism and Shinto who does not prohibit the use of pigs and alcholol in cooking. Although many Japanese people who eat fish and vegetables, but many sauces that are used are contain lard or alcohol so it is not lawful for Muslim consumption. Muslims who want to visit Japan has concerns trouble getting Halal food that can cause them to change their mind to go to Japan.

Although not all foods containing pork or alcohol but because of differences in language that makes Muslim tourists visiting Japan do not understand any material contained in the food or how to make it and they dont want take risk of eating non Halal food.

Japan is becoming an increasingly popular destination for Muslim travellers. In a bid to attract larger numbers of Muslim travellers, Japan is restructuring its tourist industry in order to better serve the specific needs of Muslims. The importance of the Muslim travel market segment is being realised by numerous countries around the world, with many deciding to embrace Halal tourism. One such country is Japan. Japan was visited by over 300,000 Muslim travellers in 2013 and visitor numbers are expected to soar to over a million yearly Muslim visitors by the year 2020. A large majority of visits come from South East Asian countries such as Indonesia, Malaysia and Singapore and account for around $65 \%$ of all Muslim visitors to Japan.

The increasing number of Muslim tourists from various countries to Japan make the government of Japan start to implement the concept of Muslims Friendly so that Muslim travelers visiting Japan do not worry about the food over there. The concept of Muslim Friendly which applied by the Japanese government not only Halal food but including a place for pray and hotels.

Culinary experiences can add value to tourism by providing the tourist with a link between local culture, landscape and food, and by creating the 'atmosphere' so essential to a memorable travel experience (Hjalager and Richards, 2002). Destinations can capitalize on cultural assets and elements of culinary tourism unique to their community for destination image building (Hall and Mitchell, 2005).

Culinary resources include raw ingredients, prepared foods, and beverages reflective of the destination. Culinary resources also include traditional methods of preparing or serving foods, traditional or innovative recipes featuring local ingredients, and agricultural practices or food production techniques distinctive to the destination.

\section{RESEARCH METHOD}

This study uses a qualitative method. In order to obtain primary data using observation, survey, documentation and literature study. Observation is made when the author visited Tokyo in January and April 2016. Tokyo is the capital of Japan. Lots of foreign tourists will visit Tokyo because Tokyo has many tourist attraction. Tokyo also provide a lot of 
Japanese culinary such as sushi, ramen, udon, katsu , teriyaki, and others. During the observation, author found that are some halal restaurants in Tokyo that provide halal food that can be consumed by muslim travellers. One of the halal restaurant that the author visited was Narita-ya that located in Asakusa. The restaurant provides fresh noodles (uses domestic wheat) that are being made at their own factory. Usually Japanese ramen soup is made from pork broth. But, the ramen soup in this restaurant is chicken based flavor and the ingredients are all composed by carefully selected items. This restaurant wanting people from around the world to be able to enjoy the ramen and not just Japanese, the entire menu selection is provided without any use of pork or alcohol. Aromatic broiled chicken is being used as a substitute for roasted pork fillet.

The repondents for this research were random sampling from Indonesia population because the author is from Indonesia and Indonesia has the most muslim population worldwide. The questions asked to the respondents are :

a. Do you like Japanese food?

b. Do you like Ramen, Sushi, or Teriyaki?

c. Is Japanese food fits with your tongue?

d. Do you like Japanese food preparation?

e. Do you like the atmosphere of a Japanese restaurant?

f. Do you love to eat at a Japanese restaurant?

g. Do you like to buy Japanese food in the food stall?

h. If you are visiting Japan would you like to eat seafood menu? (give a reason)

i. If you are visiting Japan would you like to buy food made from chicken or beef without halal logo? (Give a reason)

j. Are the availability of halal culinary in Japan makes you interested in visiting Japan?

The author also searched articles, journals, and book to support the author research result. As Islam encourage travelling, the teaching let some allowances in daily religious routines during travelling, for instance they are allowed to shorten and combine their prayers from 5 times to 3 times a day, to delay fasting in Ramadhan month, to take ablution by tayamum and to pray in any position (usually seating position) applicable when they are in the airplane (Din 1982; Hashim, Murphy, and Mohammad 2006; Henderson 2009).

However, Muslim travelers are demanded to adhere to stipulation of dress, conduct, food and prayer (ZamaniFarahani and Henderson, 2009). For example, mixing among non-mahram women and men, gambling, alcohol drinking, inappropriate dressing by exposing other than face and hands for women (aurah), consumption of non-halal food, unpermitted entertainment for instance disco and involve in prostitution are to be prohibited during travelling (Din 1982; Hashim, Murphy, and Mohammad 2006).

Many of non-Muslim countries such as Japan embarks to provide a comfortable tourist experience for Muslim. The Muslim needs such as a proper place to pray and food have been provided to ensure the convenience of Muslim tourists. For example, at both Narita and Kansai International Airport, there are more prayer rooms being made available for Muslims and the popular Japanese food such as Udon and Ramen are certified Halal so that Muslim tourists could treasure Japanese food (www.halalmediajapan.com). In addition, a prayer room is also available at shopping complex such as in AEON or Takashimaya Tokyo. For Halal food, many Halal restaurants are mushrooming in big cities of Japan such as Tokyo, Kyoto and Osaka and many main restaurants have obtained Halal certification.

Halal represents Islamic law based on the teaching of The Holy Quran and Sunnah and regulates every aspect of every Muslim's life. More specifically, Halal, literally meaning lawful or licit in Arabic, functions as a constitutive element of Islamic law, (Mukherjee, S. R., 2014) which is permitted, with respect to which no restriction exists, and the doing of which Allah has allowed (Islam, T., \& Chandrasekaran, U.,2013).

In recent years, Kansai International Airport (KIX), which is concentrating in Halal measure, explains Halal as follows. "Halal is an Arabic word which means lawful in Sharia, and refers to what a Muslim can eat satisfactorily. In general it is required to carry out the contraindications of pork, alcohol, and its derivative, and to be processed according to Sharia also about the other foods, and it is also forbidden that Halal food and the other food contact." (Extract from KIX News Release 2013.8.13)

Each country has a certification system of Halal. A Halal logo can be used, after obtaining certification. A Halal certification system is similar to the certification system of ISO. ISO guarantees its process in comparison with being the system that JAS (Japanese Agricultural Standard) and JIS (Japanese Industrial Standards) guarantee product itself. ISO, as a result, can guarantee a product by guaranteeing a process. The process is also important for Halal certification. Moreover, not only in goods but also in certificating service, management, etc., Halal is close to the way of thinking of ISO. There are some organization in Japan that issued Halal certificate such as Japan Halal Association, Japan Asia Halal Association, Japan Islam Culture Center, and Japan Muslim Association.

The Halal restaurants and hotels are common problem that non-Islamic countries have. As the promotion of Japanese government, Japan National Tourism Organization (JNTO) has produced a new travel guide for Muslim visitors, which provides general tourism information as well as a list of halal restaurants in Japan (Japan Travel Guide for Muslim Visitors by JNTO, 2013).

The results of previous researched were consistent with the analyses of the three countries for the purposes of brand awareness, association, and loyalty. Overall, Malaysian Muslims perceived Japan as having the most favorable destination brand positioning, followed by Korea and China (Seongseop Sam Kim, Holly Hyunjung Im and Brian EM King 2014).

\section{RESULT}

Based on research from articles, journals and observation, most big cities in Japan like Tokyo, Osaka, Kyoto, and 
Sapporo already have Halal Japanese restaurants to service Muslim travellers that visit their town.

Big cities in Japan also provide a tourist guide for Muslim travellers that includes information about Japanese Halal restaurants and prayer room or mosque in their area. There are some varieties of Halal Japanese culinary that can be found now, such as Ramen, Udon, Sushi, Shabu-Shabu, Gyoza, Kare, Soba, and many more.

Halal Japanese restaurants already had Halal logo, so it easier for Muslim travellers to identified. Based on the author experienced during trip to Japan on April 2016. There are also restaurants that dont have Halal logo yet, but they mentioned it safe to consume for muslim travellers by putting the Halal tag in the dish because the equipments and ingredients are separated with non-Halal food.

Based on the surveyed from 30 respondents. $70 \%$ of respondents like Japanese culinary. $90 \%$ like Japanese restaurant atmosphere. The questionaire asked about the if their visit Japan will they eat Japanese seafood or not. $70 \%$ of repondents answered yes because they like seafood and it safe to consume. $30 \%$ answered no with reasons have allergic or they dont like seafood. The questionare also asked if their visit Japan, will they eat chicken or beef without halal logo. $23 \%$ answered yes because they said it safe to consume. $77 \%$ answered no with reason they uncertain about the halalness and affraid the food are contaminated with non-halal food. Last question was, are they interested to visit Japan if Halal food are available in there. $93 \%$ of respondents answered yes and $7 \%$ answered no.

\section{CONCLUSION}

Based on the researched, it can be concluded that Japanese government together with Muslim organization in Japan are eager to develop Halal tourism in Japan to attract more muslim travellers.

Halal tourism include with availabilty of Halal culinary in Japan. Many of Japanese restaurants spread around the world including in Indonesia. But, of course people want to try the food from the origin places. Culinary experiences can add value to tourism by providing the tourist with a link between local culture, landscape and food, and by creating the 'atmosphere' so essential to a memorable travel experience (Hjalager and Richards, 2002).

Based on the researched, the availabilty of Halal Japanese culinary can increase the number of Muslim travellers interested in visiting Japan. A Muslim has obligation to eat Halal food which is difficult to find in Japan in the previous time. Now, Japan government try to provide Japanese Halal culinary so that Muslim travellers that visit Japan can eat Japanese food they like without having worry about the Halalness.

They also hope that they strategies to develop Halal tourism can attract more Muslim travellers to visit Japan.

\section{REFERENCES}

Asazuma Takumi. Halal industry activates Japanese tourism market. Retrieved from: http://human.kanagawa u.ac.jp/gakkai/student/pdf/i11/110320.pdf

Crescent Rating : Japan welcomes Halal tourism Retrieved from:

https://www.crescentrating.com/magazine/opinion/3658/j apan-welcomes-halal-tourism.html

Din, H. Kadir (1982). Tourism in Malaysia: Competing needs in the plural society. Annals of Tourism Research 9:453480

Hall, C. M. and Mitchell, R. 2005 'Gastronomic Tourism: Comparing Food and Wine Tourism Experiences', in $\mathrm{M}$. Novelli (ed.) Niche Tourism: Contemporary Issues, Trends and Cases. Oxford: Butterworth

Hashim, Noor Hazarina, Jamie Murphy, and Nazlida Mohammad. (2006). Tourism and Islam: Understanding and embracing opportunities. From The Experts

Henderson, Joan C. (2003). Managing Tourism and Islam in Peninsular Malaysia. Tourism Management 24 (4):447456

Hjalager, A. M. and Richards, G. (2002). Tourism and Gastronomy. London and New York: Routledge

Islam, T., \& Chandrasekaran, U. (2013). Halal Marketing: Growing The Pie. International Journal of Management Research and Reviews, 3(12), 3938

Mukherjee, S. R. (2014). Global halal: Meat, money, and religion. Religions, 5(1), 22 . doi:10.3390/rel5010022

Nor Zaid Md. Salleh . (2015). Final Report: "Developing the non-Muslim tourist destination for Muslim tourists: A case study of Akita Prefecture, Japan" Retrieved from: http://web.aiu.ac.jp/iasrc/wpontent/uploads/2015/03/final- report-Muslim- touristin-Akita.pdf

Riyad Eid and Hatem El-Gohary. Muslim Tourist Perceived Value in the Hospitality and Tourism Industry. Retrieved from : http://jtr.sagepub.com. scihub.cc/content/54/6/774.abstract

Seongseop (Sam) Kim, Holly Hyunjung Im and Brian EM King. Muslim travelers in Asia: The destination preferences and brand perceptions of Malaysian tourists. Retrieved from: http://jvm.sagepub.com.scihub.cc/content/21/1/3.abstract

Smith, Sylvia and Carol Costello. 2008. Culinary tourism: Satisfaction with a culinary event utilizing importanceperformance grid analysis. Journal of Vacation Marketing Volume 15 Number 2. Retrieved from http://jvm.sagepub.com.scihub.cc/content/15/2/99.abstract

Stephen L. J. Smith and Honggen Xiao. 2008. Culinary Tourism Supply Chains: A Preliminary Examination. Journal of Travel Research 2008 46: 289. Retrieved from http://jtr.sagepub.com.sci-hub.cc/content/46/3/289.

Suhadi. The Development of Halal Food in Japan: Tourism and Muslim's Identity Construction in Japan (Case Study in Tokyo and Osaka) Retrieved from: http://www.sumitomo.or.jp/pdf/jare/13_jare_seika/jare1327.pdf

Takayuki Mori. "The present condition and the subject of Halal in Japan, In comparison with Malaysia" Retrieved from : http://www.cai.ku.ac.th/Paper-SARD/paper34.pdf

Zamani-Farahani, Hamira, and Joan C. Henderson. (2009). Islamic tourism and managing tourism development in Islamic societies: the cases of Iran and Saudi Arabia. International Journal of Tourism Research 12 (1):79-89 